\title{
О ПАЛЕОПАТОЛОГИИ ВЕРХНЕМЕЛОВЫХ ПЛЕЗИОЗАВРОИДОВ НИЖНЕГО ПОВОЛЖЬЯ
}

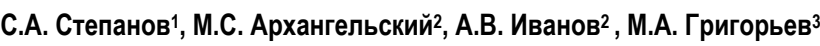 \\ ${ }^{1}$ Саратовский государственный медицинский университет, \\ кафедра патологической анатомии \\ E-mail: paleozoo@san.ru \\ 2 Саратовский государственный университет, \\ кафедра исторической геологии и палеонтологии \\ E-mail: paleozoo@san.ru \\ 2 Саратовский государственный университет, \\ кафедра геоэкологии \\ E-mail: geoecologia@info.sgu.ru \\ 3 Палеонтологический клуб «Тетис», Саратов
}

Описаны остатки плезиозавроидов со следами механических травм (укусов) и палеопатологических изменений в костной ткани. Весь описанный костный материал происходит из верхнемеловых отложений территории Нижнего Поволжья.

On Paleopathology of the Upper Cretaceous Plesiosauroid Sauropterygians of the Lower Volga-Region

\section{S.A. Stepanov, M.S. Arkhangelsky, A.V. Ivanov, M.A. Grigoriev}

Plesiosauroid sauropterygian remains with mechanical traumas (predator's bites) and paleopathological modifications in bone structure were described from the Upper Cretaceous deposits of the Lower Volga region.

Незначительное количество сведений о палеопатологических изменениях в костях морских мезозойских пресмыкающихся, a следовательно, малое количество публикаций, посвященных данной тематике, ранее отмечалось авторами. Нами был приведен немногочисленный библиографический список по данному вопросу [1-3]. В связи с этим возникает необходимость дальнейших исследований в данном направлении.

Значительный интерес представляет описываемый ниже ряд находок остатков завроптеригий со следами механических травм и палеопатологических изменений костной ткани. Весь остеологический материал происходит из верхнемеловых отложений Саратовской и Пензенской областей [4].

Среди имеющегося в распоряжении авторов материала сохранился незначительный фрагмент левого коракоида (экз. СГУ №104a/39), несущий фасетки для формирования гленоидной впадины и контакта с лопаткой (см. рис. 1 на вклейке 2). Кость происходит из нижнекампанского фосфоритово-

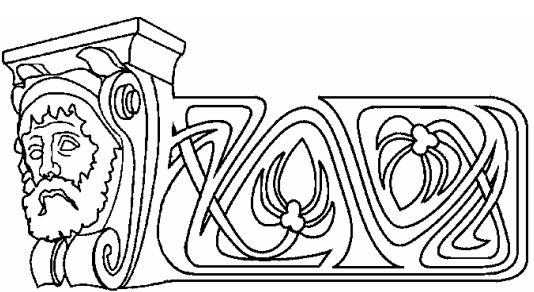

го горизонта местонахождения «Широкий Карамыш-2» (Лысогорский район, Саратовская область). Длина фасетки для сочленения с лопаткой составляет 28 мм; длина фасетки, участвующей в формировании гленоида 58 мм. На вентральной поверхности кости ближе к суставному сочленению располагается глубокая борозда клиновидной формы и неравномерной глубины. Отрезок борозды, при-мыкающий к суставной поверхности, имеет глубину 6 мм и ширину 4,5 мм. Противоположный конец борозды выходит на поверхность костной ткани и имеет незначительное углубление (0,2 мм). Длина борозды - 33 мм. На этой же поверхности прослеживаются еще три параллельно идущие борозды равномерной глубины (0,5 мм). Их длина соответственно составляет - 18 мм, 27 мм, 18 мм. Первые три борозды располагаются на равном друг от друга расстоянии, составляющем 8 мм. Четвертая борозда находится в 20 мм от третьей. Все борозды слабо изогнуты. Можно предположить, что указанные структурные изменения на костной поверхности связаны с механическим повреждением - укусом. Следы регенерации костной ткани отсутствуют, и повреждение, видимо, являлось посмертным.

В коллекции имеется левый propodium взрослой особи (экз. СГУ № 104a/40), обнаруженный в нижнекампанском фосфоритовом горизонте местонахождения «Карякино» (Татищевский район, Саратовская область). Длина кости составляет 327 мм, ширина дистального эпифиза - 170 мм, проксимального - 67 мм, диафиза - 80 мм. На дорсальной 
поверхности проподия располагаются четыре параллельно идущие борозды различных размеров (длина - от 11 до 32 мм, ширина 2-3 мм, глубина - 0,5-1,5 мм) (см. рис. 2 на вклейке 2). Борозды располагаются в области диафиза и направлены в постеро-проксимальном направлении. Края борозд ровные, сглаженные. Расстояние между бороздами от 9 до 18 мм. Расстояние между крайними бороздами - 63 мм. Следы регенерации костной ткани также отсутствуют и укус, видимо, также был нанесен посмертно.

На вентральной поверхности у основания проксимального эпифиза на костной поверхности имеются углубления различной формы, максимальный размер которых не превышает 2-3 мм. Вследствие этого поверхность костной ткани выглядит бугристой.

Сходный характер костной поверхности отмечен на фрагменте проксимального эпифиза крупного проподия взрослой особи (экз. СГУ №104a/41) из верхнетуронского фосфоритового горизонта местонахождения «Красный Текстильщик» (Саратовский район, Саратовская область) (см. рис. 4 на вклейке 2). Сохранившаяся длина фрагмента - 221 мм, ширина у основания эпифиза - 75 мм. Здесь поверхность костной ткани зернистая, бугристая, узелковая, покрыта углублениями диаметром от 2 до 14 мм, с редкими гаверсовыми каналами. Указанная поверхность костной ткани являлась местом прикрепления мощных сухожилий мышечной ткани. Однако неровно-узелковый характер ткани указывает на наличие оссификатов, предпосылкой развития которых могли быть изменения кальциевого и минерального обмена.

Значительный интерес представляет фрагмент кости ?нижней челюсти (экз. СГУ № 104a/42), обнаруженный в нижнекампанском фосфоритовом горизонте местонахождения «Белый Ключ» (Сердобский район, Пензенская область). Сохранившаяся длина 240 мм, сохранившаяся высота - 92 мм. На поверхности фрагмента имеется дефект неправильно-овальной формы (размер 62×66 мм, глубина около 14 мм), местами окруженный выступающим валиком. Дно дефекта крупнобугристое, местами с ямками. Наличие указанного углубления может свидетельствовать о хроническом процессе (типа остеомиелита), связанном с распадом костной ткани (см. рис. 3 на вклейке 2). Аналогичные изменения были описаны нами в ранее опубликованной работе [3].
Определенный интерес представляет описание неполного propodium'a ювенильной особи (экз. СГУ №104a/43) из нижнесеноманского фосфоритового горизонта местонахождения «Шаблиха» (Саратовский район, Саратовская область) (см. рис. 5 на вклейке 2). Сохранившаяся длина проподия составляет 214 мм. Эпифизы не сохранились. Ширина диафиза - 56 мм. Кость сильно окатана. На дорсальной и вентральной поверхностях кости располагаются углубления полуовальной формы с пологими краями и гладкой прошлифованной поверхностью. Диаметр их достигает 10-13 мм. На дорсальной поверхности, ближе к проксимальному эпифизу, они группируются в участок площадью около $34 \times 41$ мм. На заднем крае propodium'a имеется незначительное субовальное гладкое (длиной 49 мм) прошлифованное углубление, ограниченное слабыми гребнями и несущее единственный гаверсов канал диаметром 0,5 мм. Расположение углублений нехарактерно для строения нормальной костной ткани и может быть следствием давления на ее поверхность, скорее всего, очагов гнойного воспаления, ограниченных толстой фиброзной капсулой. Подобные процессы приводили к мощным абсцессам. Propodium ювенильной особи с идентичными патологическими изменениями ранее уже был описан авторами [3].

Авторы выражают искреннюю благодарность М.Ю. Григорьеву, И.В. Архангельской, М.С. Ивкину и Е.В. Попову (Саратовский государственный университет) за любезную помощь, оказанную при подготовке статьи.

Работа выполнена при финансовой поддержке РФФИ (проект 05-05-65157).

\section{Библиографический список}

1. Степанов С.А., Архангельский М.С., Иванов А.В. О палеопатологии Ichthyopterygia // Вопросы палеонтол. и стратигр. верхнего палеозоя и мезозоя (памяти Г.Г. Пославской). Саратов, 2004. С.168-171 (Тр. Науч.-исслед. инта геологии Сарат. гос. ун-та. Нов. сер. T.XVI).

2. Степанов С.А., Архангельский М.С., Иванов А.В., Успенский Г.Н. О палеопатологии ихтиоптеригий // Архив Патологии. 2004. №2. С.29-31.

3. Степанов С.А., Архангельский М.С., Иванов А.В. О палеопатологии Sauropterygia // Недра Поволжья и Прикаспия. 2005. №43. С.28-31.

4. Первушов Е.М., Архангельский М.С., Иванов А.В. Каталог местонахождений остатков морских рептилий в юрских и меловых отложениях Нижнего Поволжья. Саратов, 1999. 232 c. 

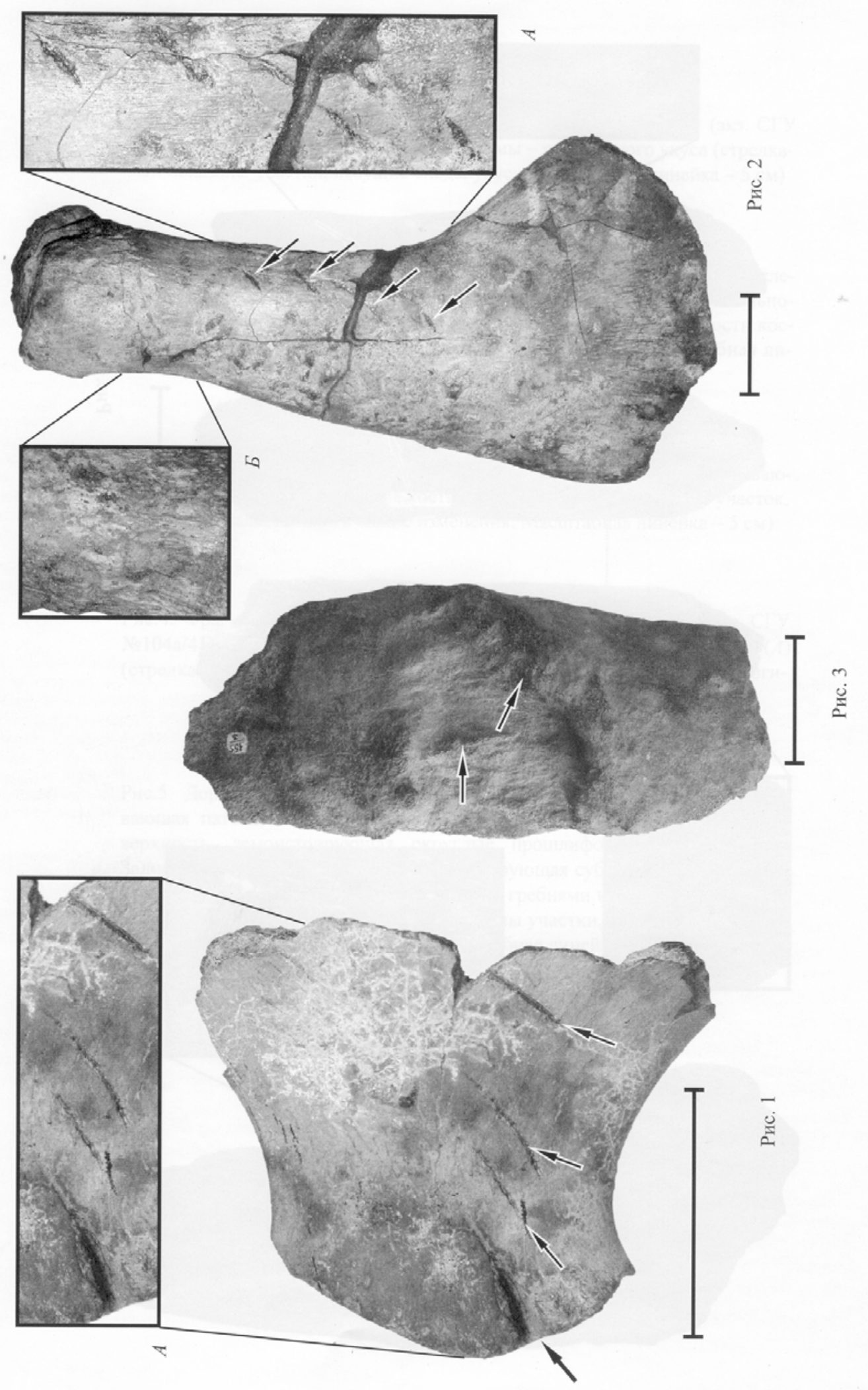

(C) С.А. Степанов, М.С. Архангельский, А.В. Пванов, М.А. Григорьев, 2006 


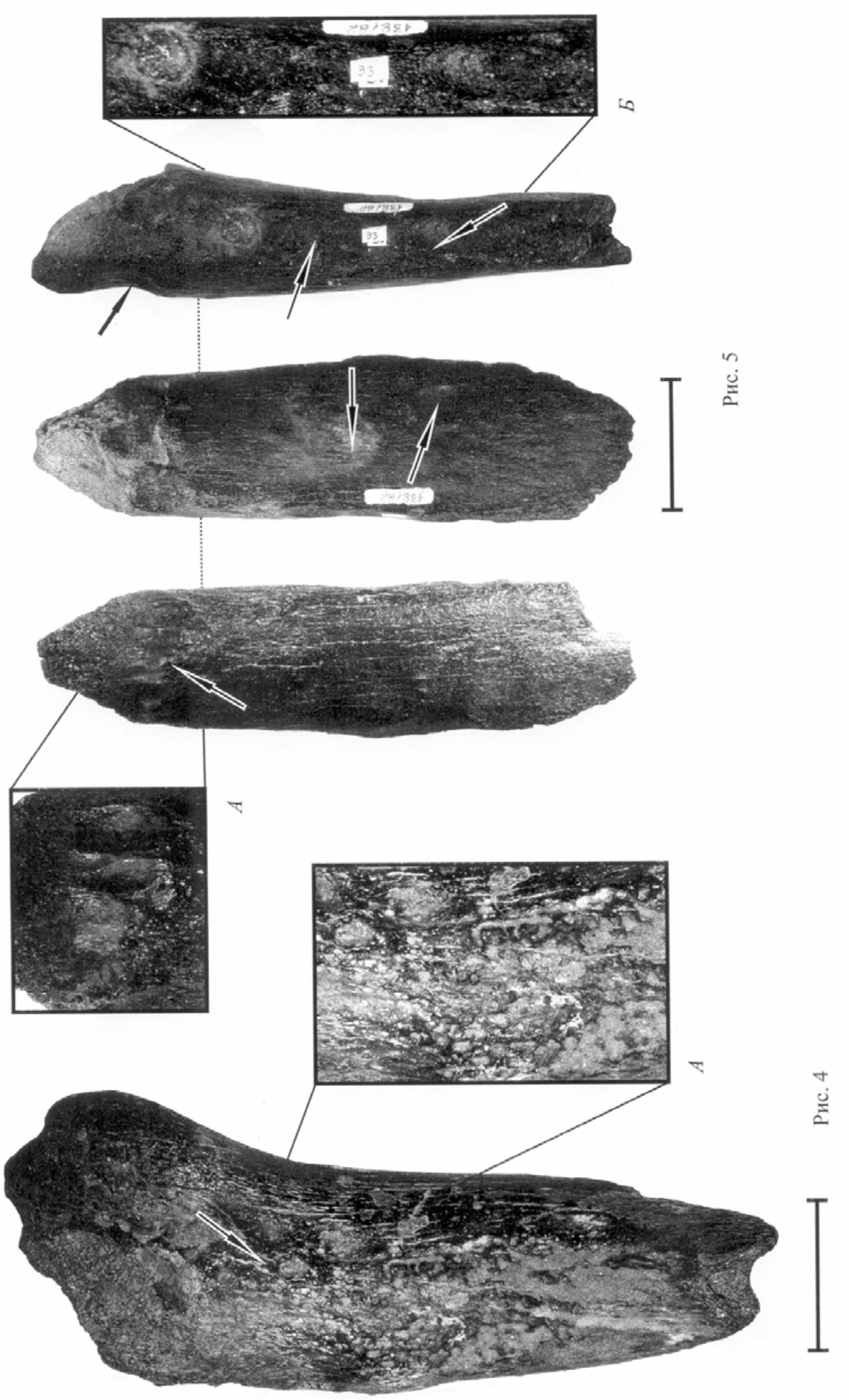


Рис.1. Вентральная поверхность неполного левого коракоида (экз. СГУ №104a/39): $A$ - следы механической травмы - посмертного укуса (стрелками показаны участки, несущие следы укуса. Масштабная линейка - 5 см)

Рис.2. Дорсальная поверхность левого propodium (экз.СГУ №104a/40): $A$ - следы механической травмы - посмертного укуса; $\overline{-}$ - область проксимального эпифиза, показывающая наличие узелково-бугорчатой поверхности кости (стрелками показаны участки, несущие следы укуса. Масштабная линейка -5 см)

Рис.3. Фрагмент кости ?нижней челюсти (экз. СГУ №104a/42), показывающий патологические изменения костной ткани (стрелками показан участок, несущий палеопатологические изменения. Масштабная линейка -5 см)

Рис.4. Фрагмент проксимального эпифиза крупного propodium (экз. СГУ №104a/41), демонстрирующий наличие бугорчато-узелковой ткани $(A)$ (стрелками показаны участки, предположительно несущие палеопатологические изменения. Масштабная линейка -5 см)

Рис.5. Дорсальная поверхность propodium (экз. СГУ №104a/43), показывающая патологические изменения костной ткани $(A)$. Вентральная поверхность, демонстрирующая округлые прошлифованные углубления. Задняя поверхность propodium, демонстрирующая субовальное прошлифованное углубление, ограниченное слабыми гребнями и несущее единственный гаверсов канал (Б) (стрелками показаны участки, несущие палеопатологические изменения. Масштабная линейка -5 см) 